\title{
Perancangan Sistem Pendukung Keputusan Kelayakan Penerima Beasiswa Untuk Siswa Tidak Mampu Dengan Metode AHP Menggunakan Visual Basic 2010
}

\author{
Jalasena Dwi Putra ${ }^{1}$, Dadan Zaliluddin ${ }^{2}$, Dede Abdurahman ${ }^{3}$ \\ ${ }^{1,2,3}$ Program Studi Informatika Fakultas Teknik Universitas Majalengka \\ Jalan K.H. Abdul Halim No.103 Majalengka, Jawa Barat \\ ${ }^{1}$ jalasenadp@gmail.com \\ 22dadanzuu@gmail.com \\ dzildan@gmail.com
}

\begin{abstract}
Abstrak - UPTD Pendidikan Kecamatan Sukahaji merupakan salah satu Unit Pelaksanaan Teknis Dinas Pendidikan yang terletak di Desa Sukahaji Kecamatan Sukahaji. Beasiswa harus diberikan kepada penerima yang layak dan pantas untuk mendapatkannya. Proses seleksi yang berhak menerima beasiswa masih mengalami kendala pada proses hasil pengambilan keputusan. Karena banyaknya siswa dan kriteria yang ditentukan untuk memberikan keputusan penerima beasiswa yang sesuai dengan yang diharapkan. Sistem pendukung keputusan dengan metode Analytic Hierarchy Process (AHP) memberikan kemudahan dengan penilaian kriteria majemuk dengan suatu kerangka berfikir yang komprehensif pertimbangan proses hirarki yang kemudian dilakukan perhitungan bobot untuk masing-masing kriteria dalam menentukan kelayakan pemberian beasiswa yang akan menghasilkan laporan prioritas calon penerima beasiswa. Adapun tujuan dilakukannya penelitian Tugas Akhir ini adalah untuk merancang dan membuat suatu sistem pendukung keputusan (SPK) untuk pemilihan beasiswa serta agar beasiswa dapat diberikan tepat kepada siswa yang layak menerimanya.
\end{abstract}

Kata Kunci : $\quad$ Sistem Pendukung Keputusan, Kelayakan Penerima Beasiswa, Siswa Tidak Mampu, AHP, Visual Basic 2010

\section{PENDAHULUAN}

Beasiswa dapat dikatakan sebagai pembiayaan yang tidak bersumber dari pendanaan sendiri atau orang tua, tetapi diberikan oleh pemerintah, perusahaan swasta, kedutaan, universitas, serta lembaga pendidik atau peneliti, atau juga dari kantor tempat bekerja yang karena prestasi seseorang dapat diberikan kesempatan untuk meningkatkan kapasitas sumber daya manusianya melalui pendidikan. Biaya tersebut diberikan kepada yang berhak menerima, terutama berdasarkan klasifikasi, kualitas, dan kompetensi penerima beasiswa.

Sesuai penjelasan yang tercantum dalam UUD 1945 bahwa salah satu hak azasi manusia yang paling mendasar adalah memperoleh pendidikan yang layak. Ketika seseorang memperoleh pendidikan yang baik, akan terbuka baginya untuk mendapatkan kehidupan yang lebih baik. Menyadari bahwa pendidikan sangat penting, negara sangat mendukung setiap warga negaranya untuk mendapat pendidikan setinggitingginya. Salah satunya dengan melakukan program beasiswa.

Sistem pendukung keputusan dengan metode Analytic Hierarchy Process (AHP) memberikan kemudahan dengan penilaian kriteria majemuk dengan suatu kerangka berfikir yang komprehensif pertimbangan proses hirarki yang kemudian dilakukan perhitungan bobot untuk masing-masing kriteria dalam menentukan kelayakan pemberian beasiswa yang akan menghasilkan laporan prioritas calon penerima beasiswa.

Untuk itu diperlukan suatu Sistem Pendukung Keputusan (SPK) yang dapat memperhitungkan segala kriteria yang mendukung pengambilan keputusan guna membantu, mempercepat dan mempermudah proses pengambilan keputusan. Dari uraian diatas, maka dalam laporan penelitian Tugas Akhir ini penulis mengambil judul "PERANCANGAN SISTEM PENDUKUNG KEPUTUSAN KELAYAKAN PENERIMA BEASISWA UNTUK SISWA TIDAK MAMPU DENGAN MENGGUNAKAN METODE AHP"

\section{METODOLOGI PENELITIAN}

Systems Development Life Cycle (SDLC) merupakan metodologi umum dalam pengembangan sistem yang menandai kemajuan usaha analisis dan desain.

SDLC meliputi fase-fase yang menjadi proses-proses standar berikut:

1.Identifikasi dan seleksi proyek 


\author{
2.Inisiasi dan perencanaan proyek \\ 3.Analisis \\ 4.Desain \\ a Desain logikal \\ b Desain fisikal \\ 5.Implementasi \\ 6.Pemeliharaan
}

Model siklus hidup (life cycle model), adalah model utama dan dasar dari banyak model. Salah satu model yang cukup dikenal dalam dunia rekayasa perangkat lunak adalah The Waterfall Model. Ada 5 tahapan utama dalam The Waterfall Model seperti terlihat pada gambar 2.6. Disebut waterfall (berarti air terjun) karena memang diagram tahapan prosesnya mirip dengan air terjun yang bertingkat. Model ini mengambil kegiatan proses dasar seperti spesifikasi, pengembangan, validasi, evolusi, dan mempresentasikannya sebagai fase-fase proses yang berbeda seperti spesifikasi persyaratan, perancangan perangkat lunak, implementasi, pengujian, dan seterusnya.

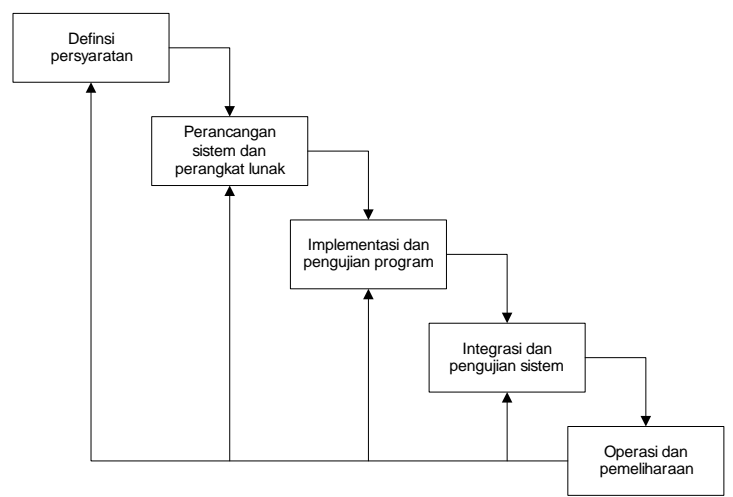

\section{Gambar 1. Model Waterfall} (Sommerville, 2003:43)

Tahap-tahap utama dari model ini memetakan kegiatankegiatan pengembangan dasar yaitu :

1. Analisis dan definisi persyaratan. Pelayanan, batasan, dan tujuan sistem ditentukan melalui konsultasi dengan user sistem. Persyaratan ini kemudian didefinisikan secara rinci dan berfungsi sebagai spesifikasi sistem.

2. Perancangan sistem dan perangkat lunak. Proses perancangan sistem membagi persyaratan dalam sistem perangkat keras atau perangkat lunak. Kegiatan ini menentukan arsitektur sistem secara keseluruhan. Perancangan perangkat lunak melibatkan identifikasi dan deskripsi abstraksi sistem perangkat lunak yang mendasar dan hubungan-hubungannya.

3. Implementasi dan pengujian unit. Pada tahap ini, perancangan perangkat lunak direalisasikan sebagai serangkaian program atau unit program. Pengujian unit melibatkan verifikasi bahwa setiap unit telah memenuhi spesifikasi.

4. Integrasi dan pengujian sistem. Unit program atau program individual diintegrasikan dan diuji sebagai sistem yang lengkap untuk menjamin bahwa persyaratan sistem telah dipenuhi. Setelah pengujian sistem, perangkat lunak dikirim kepada pelanggan.

5. Operasi dan pemeliharaan. Biasanya (walaupun tidak seharusnya), ini merupakan fase siklus hidup yang paling lama. Sistem diinstal dan dipakai. Pemeliharaan mencakup koreksi dari berbagai error yang tidak ditemukan pada tahap-tahap terdahulu, perbaikan atas implementasi unit sistem dan pengembangan pelayanan sistem, sementara persyaratan - persyaratan baru ditambahkan.

\section{HASIL DAN PEMBAHASAN}

\subsection{Analisis Sistem}

Pada analisis sistem akan dilakukan analisis terhadap sistem yang sudah ada dan menentukan segala sesuatu yang mungkin dapat dibantu dengan menggunakan sistem komputerisasi. Tujuan dari analisis sistem ini adalah untuk memperoleh gambaran tentang sistem yang akan dirancang.

Kegiatan dari hasil analisis sistem dijabarkan melalui bahasan-bahasan sebagai berikut:

1. Dasar Permasalahan Sistem

2. Rumusan Permasalahan Sistem

3. Evalusasi Permasalahan Sistem

4. Usulan Penyelesaian Permasalahan Sistem

\subsection{Dasar Permasalahan Sistem}

Sebelum masuk lebih jauh pada perancangan sistem baru akan dijelaskan lebih lanjut dari analisis prosedur sistem yang sedang berjalan. Hasil analisis ini mencakup dari prosedur dalam menentukan kelayakan penerima beasiswa untuk siswa tidak mampu.

Dari analisis prosedur sistem yang sedang berjalan didapat bahwa proses untuk menentukan kelayakan penerima beasiswa untuk siswa tidak mampu masih dilakukan secara manual sehingga terjadi banyak permasalahan dalam prosesnya.

Adapun sistem prosedur dalam menentukan kelayakan penerima beasiswa untuk siswa tidak mampu yang sedang berjalan adalah sebagai berikut :

1. Calon penerima mengajukan beasiswa.

2. Guru mengumpulkan dan mencatat data siswa calon penerima beasiswa.

3. Guru menentukan kelayakan penerima beasiswa untuk siswa tidak mampu berdasarkan kriteria atau ketentuan yang sudah ditetapkan.

4. Guru menyimpan data-data yang telah dikelola (arsip) dan membuat laporan untuk Kepala Sekolah.

Untuk lebih jelasnya bisa dilihat pada gambar berikut

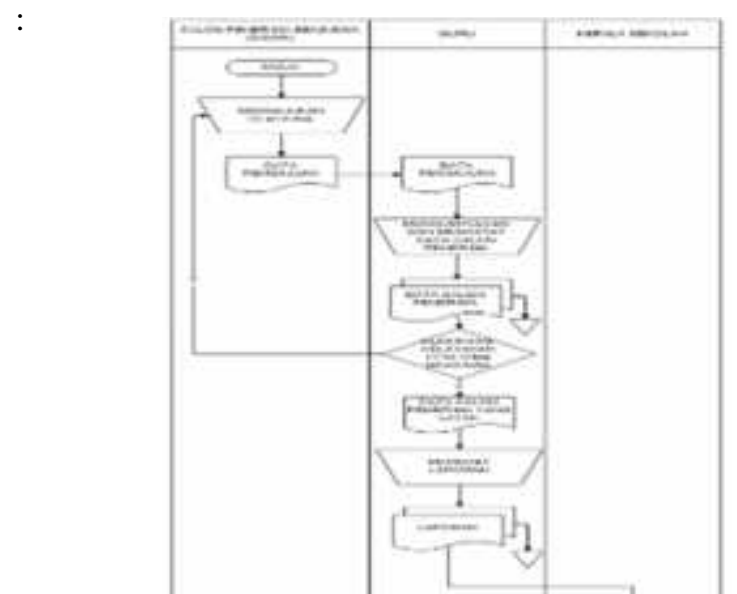




\section{Gambar 2. Diagram Alir Dokumen Berjalan}

\subsection{Usulan Penyelesaian Permasalahan Sistem}

Dalam mengatasi permasalahan yang ada perlu diperhatikan agar tidak timbul permasalahan-permasalahan yang baru dalam sistem yang diusulkan. Proses yang dilakukan pada sistem yang sedang berjalan masih menggunakan sistem manual. Proses secara manual dapat dilakukan apabila jumlah data siswa atau calon penerima beasiswa sedikit tetapi karena jumlah data tidak stabil dan selalu bertambah maka proses secara manual akan menyebabkan masalah-masalah.

Proses penentuan kelayakan penerima beasiswa untuk siswa tidak mampu yang diusulkan yaitu aplikasi sistem pendukung keputusan yang memungkinkan jumlah data siswa atau calon penerima beasiswa yang cukup banyak akan dapat dilakukan dan dikerjakan dalam waktu yang relatif singkat.

Adapun keuntungan yang dapat diperoleh sebagai berikut :

1. Tenaga yang digunakan lebih sedikit.

2. Kemudahan dan ketepatan dalam proses dapat diandalkan.

3. Tidak memerlukan tempat penyimpanan yang besar.

4. Waktu pengerjaan relatif singkat.

5. Biaya lebih hemat.

6. Pembuatan laporan menjadi lebih cepat dan mudah

Untuk lebih jelasnya mengenai usulan penyelesaian masalah dapat dilihat pada diagram alir dokumen usulan dibawah ini.

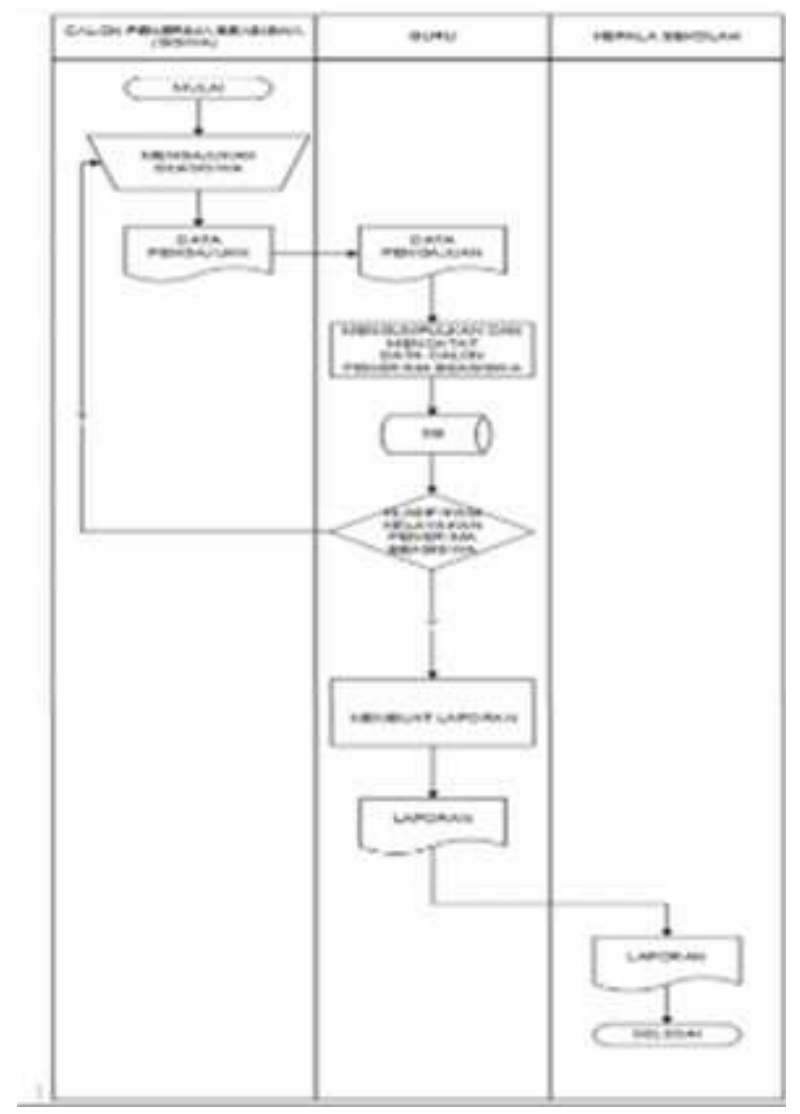

\section{Gambar 3. Diagram Alir Usulan}

\subsection{Evaluasi Permasalahan Sistem}

Hasil dari evalusasi sistem yang sedang berjalan ini adalah mengetahui adanya kelemahan dari sistem ini sehingga dapat segera ditemukan alternatif pemecahannya.

Adapun kelemahan-kelemahan yang terdapat pada sistem yang sedang berjalan adalah sebagai berikut :

1. Proses penentuan kelayakan penerima beasiswa untuk siswa tidak mampu yang dilakukan secara manual akan memakan banyak waktu dan kemungkinan terjadinya kesalahan besar seperti human error atau kesalahan lainnya.

2. Keterlambatan proses dalam menentukan kelayakan penerima beasiswa untuk siswa tidak mampu ini akan menyebabkan terhambatnya pembuatan keputusan.

3. Dengan proses secara manual, memungkinkan penyimpanan data dalam buku besar, arsip dan sejenisnya memerlukan tempat penyimpanan yang besar.

4. Keamanan data kurang terjamin, karena dengan sistem yang dilakukan secara manual semua orang dapat melakukan perubahan, sehingga data dapat dimanipulasi oleh siapapun.

Dengan melihat kelemahan-kelemahan dari sistem yang masih dijalankan secara manual, maka diusulkan sistem yang baru yaitu dengan membangun aplikasi sistem pendukung keputusan untuk menentukan kelayakan penerima beasiswa untuk siswa tidak mampu sebagai alternatif pemecahannya.

\subsection{Perancangan Sistem}

\section{A. Context Diagram}

Context Diagram yang penulis sajikan pada aplikasi sistem pendukung keputusan kelayakan penerima beasiswa untuk siswa tidak mampu ini adalah :

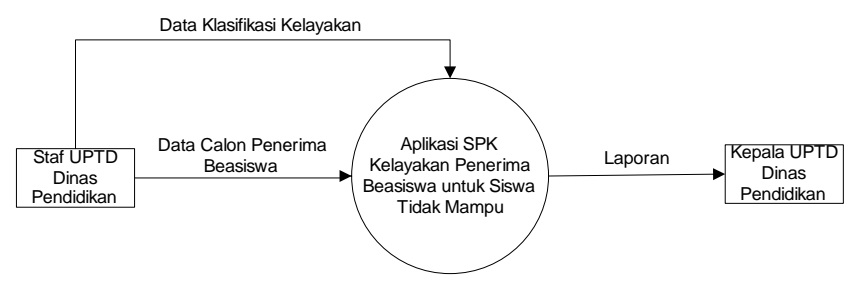

\section{Gambar 4 Conext Diagram}

\section{B. Data Flow Diagram}

Data Flow Diagram yang penulis sajikan adalah : 


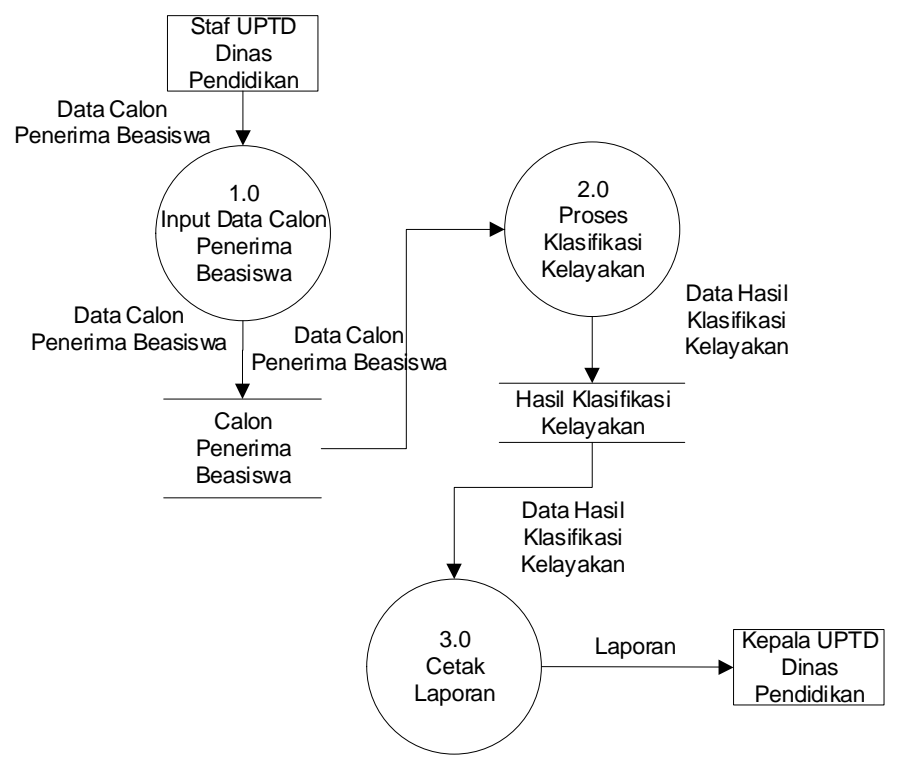

Gambar 5. Data Flow Diagram (DFD) Level 0

\section{Entity Realationship Diagram (ERD)}

Adapun perancangan Entity Realationship Diagram $(E R D)$ mengenai aplikasi ini adalah sebagai berikut :

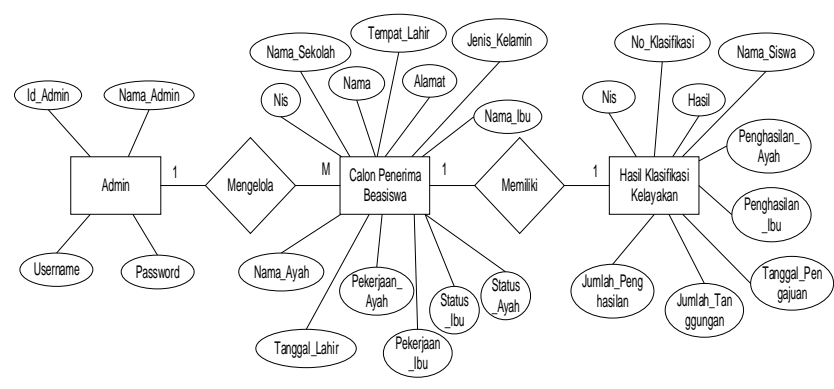

Gambar 6. Entity Realationship Diagram (ERD)

\section{Data Dictionary (Kamus Data)}

Kamus data berisi daftar atribut yang diapit kurung kurawal ('\{' dan '\}'). Adapun kamus datanya adalah sebagai berikut :

Admin $=\{\underline{\text { Id_Admin }}$, Nama_Admin, Username, Password $\}$

Calon_Penerima_Beasiswa $=\{$ Nis, Nama, Tempat_Lahir, Tanggal_Lahir, Alamat, Jenis_Kelamin, Nama_Sekolah, Nama_Ayah, Nama_Ibu, Pekerjaan_Ayah, Pekerjaan_Ibu, Status_Ayah, Status_Ibu\}

Hasil_Klasifikasi_Kelayakan $=$ \{No_Klasifikasi, Nis, Nama_Siswa, Penghasilan_Ayah, Penghasilan_Ibu,
Jumlah_Penghasilan, Jumlah_Tanggungan, Tanggal_Pengajuan, Hasil\}

\section{E. Struktur program}

Struktur program memberikan gambaran yang lebih jelas dalam penyusunan aplikasi ini.

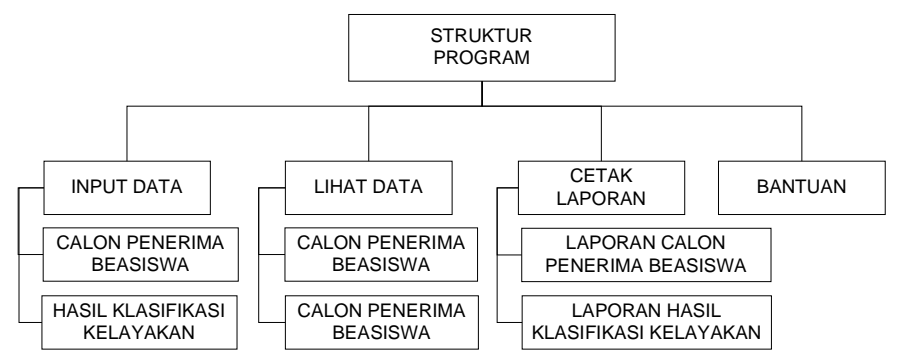

\section{Gambar 7. Struktur Program}

F. Perancangan Struktur Program

Perancangan antarmuka sistem informasi merupakan rancang bangun dari percakapan antara pemakai dengan komputer. Perancangan antarmuka ini berisi proses pemasukkan data, menampilkan output informasi kepada pemakai atau keduanya melalui layar. Perancangan antarmuka aplikasi ini adalah sebagai berikut :

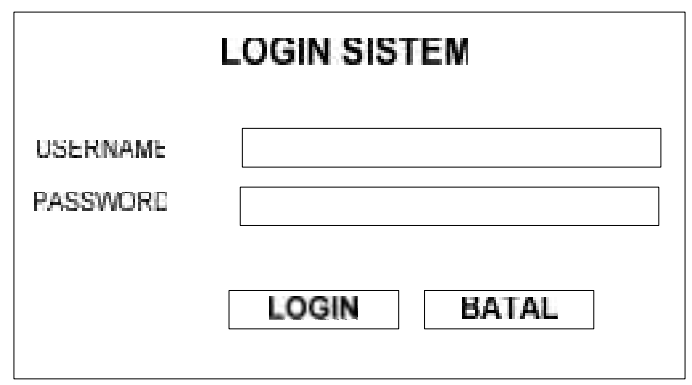

Gambar 8. Perancangan Antarmuka Login

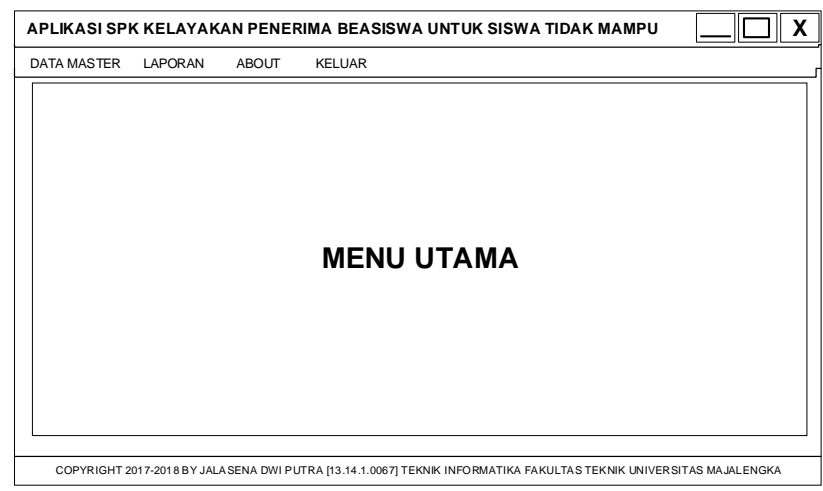


Gambar 7.Perancangan Antarmuka Menu Utama

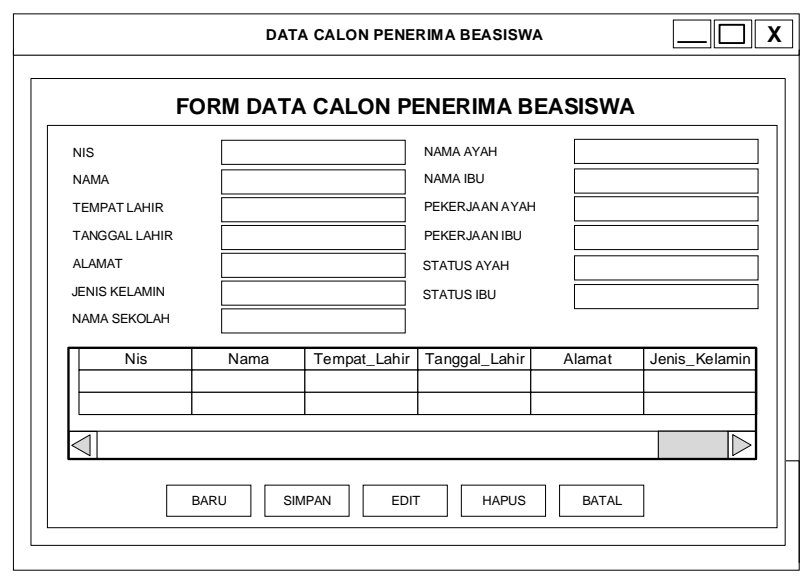

Gambar 8. Perancangan Antarmuka Data Calon Penerima Beasiswa

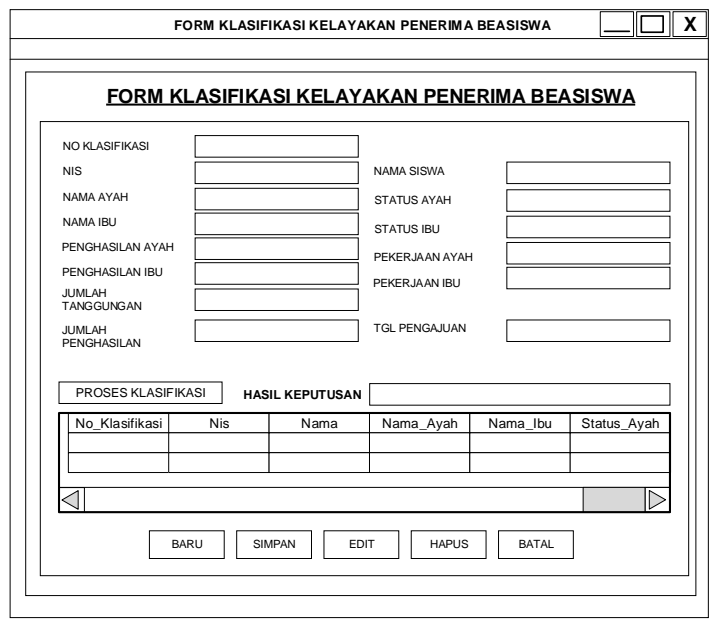

Gambar 9. Perancangan Antarmuka Data Klasifikasi Kelayakan Penerima Beasiswa

G. Implementasi Sistem

Implementasi sistem berisi tentang dokumentasi sistem yaitu tampilan atau antarmuka layar sistem.

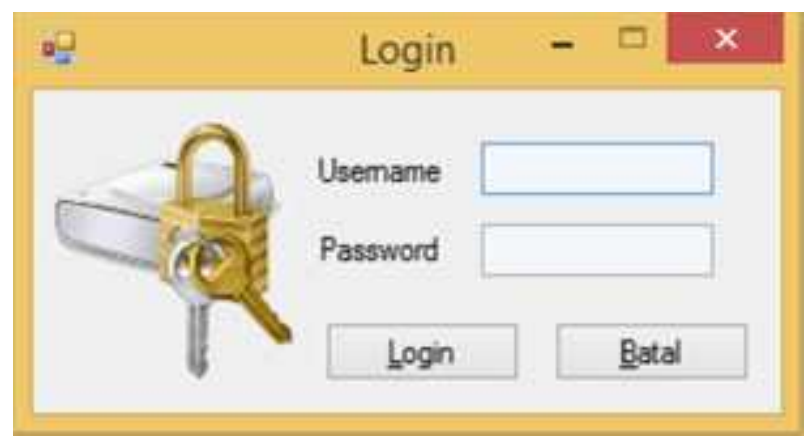

Gambar 10. Antarmuka Login

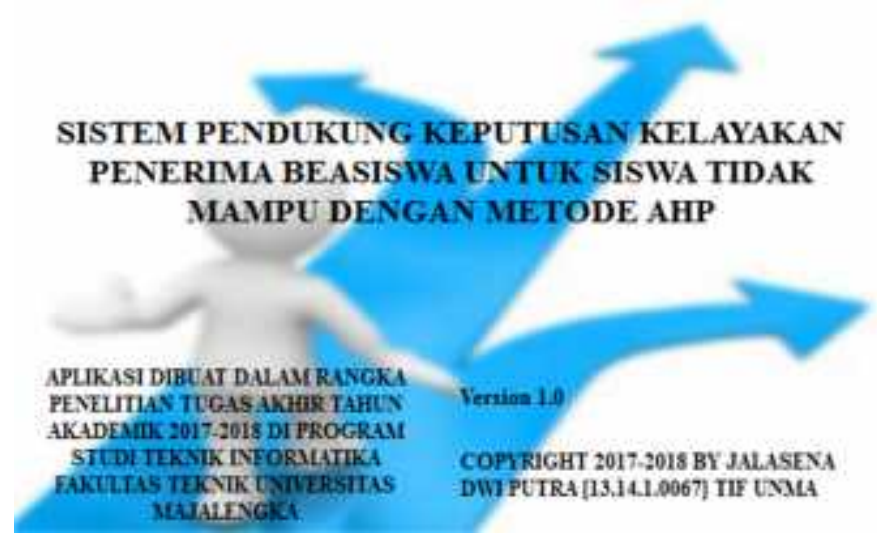

Gambar 11. Antarmuka Splash

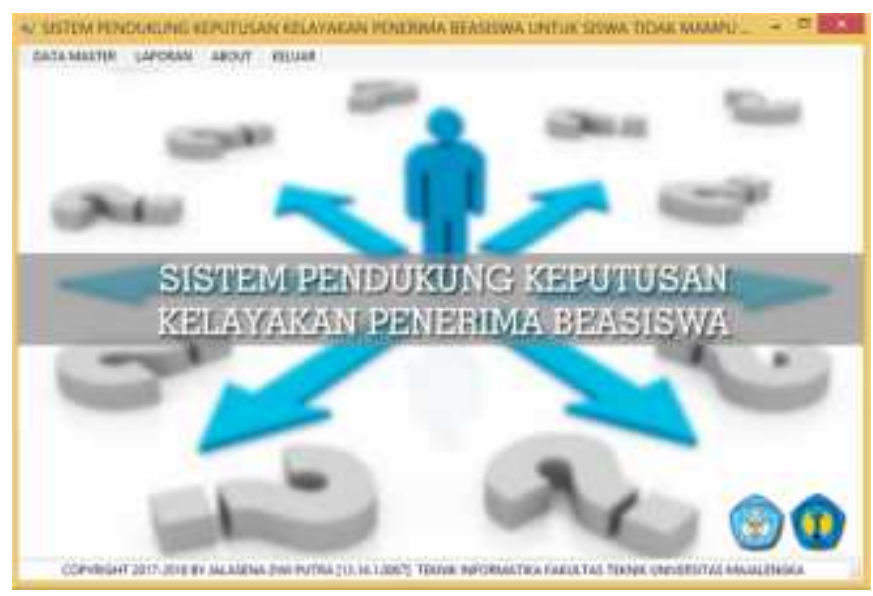

Gambar 12. Antarmuka Menu Utama

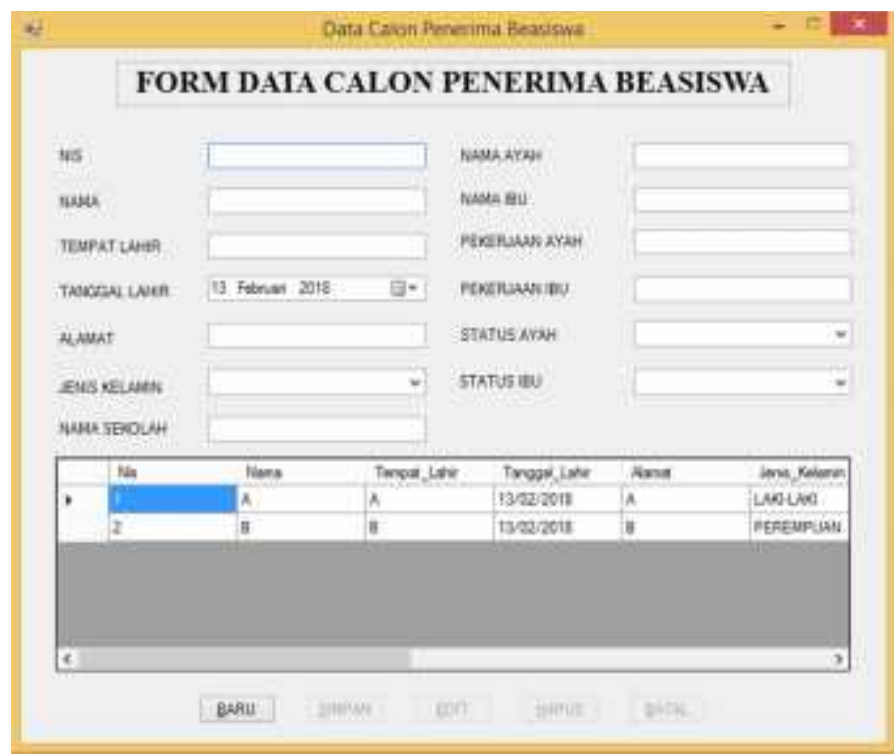

Gambar 13. Antarmuka Data Calon Penerima 


\section{Beasiswa}

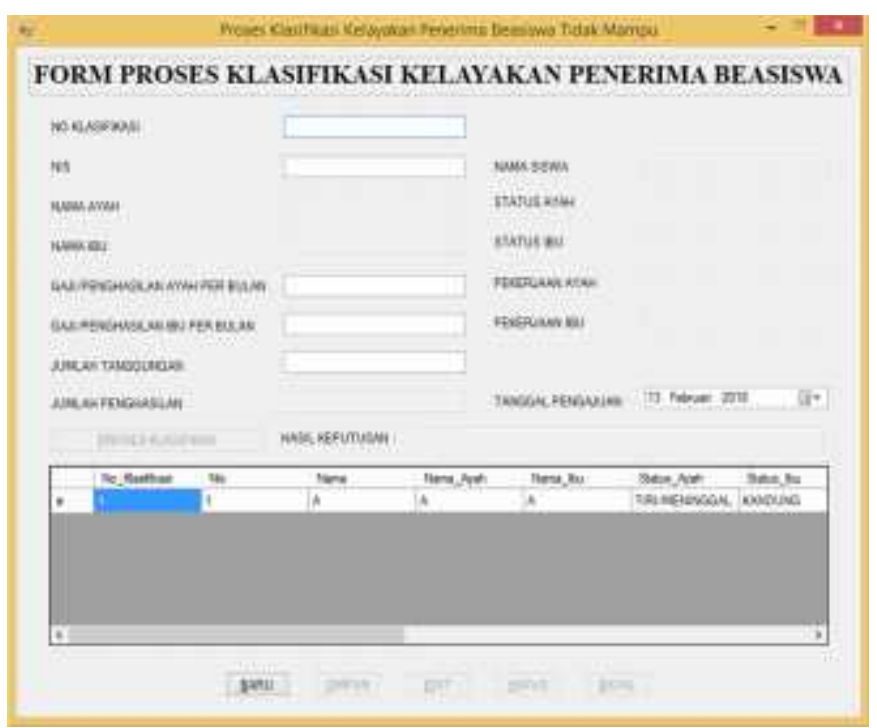

Gambar 14. Antarmuka Data Klasifikasi Kelayakan Penerima Beasiswa

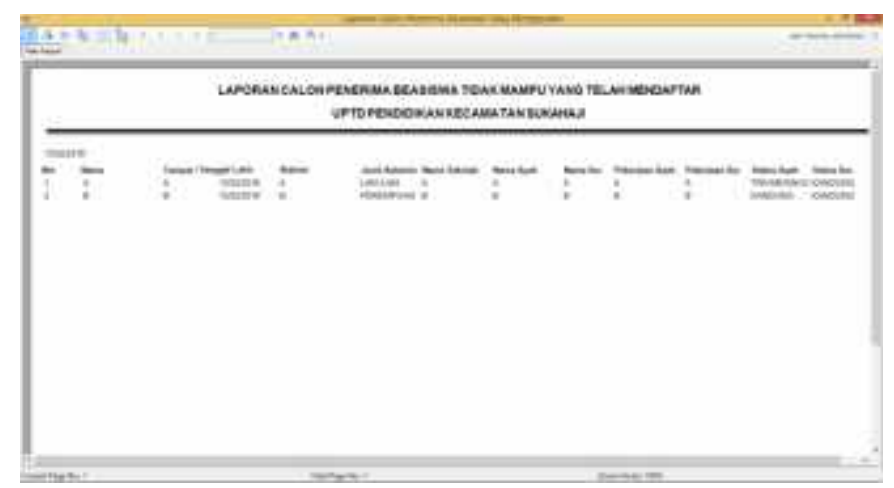

Gambar 15. Laporan Calon Penerima Beasiswa

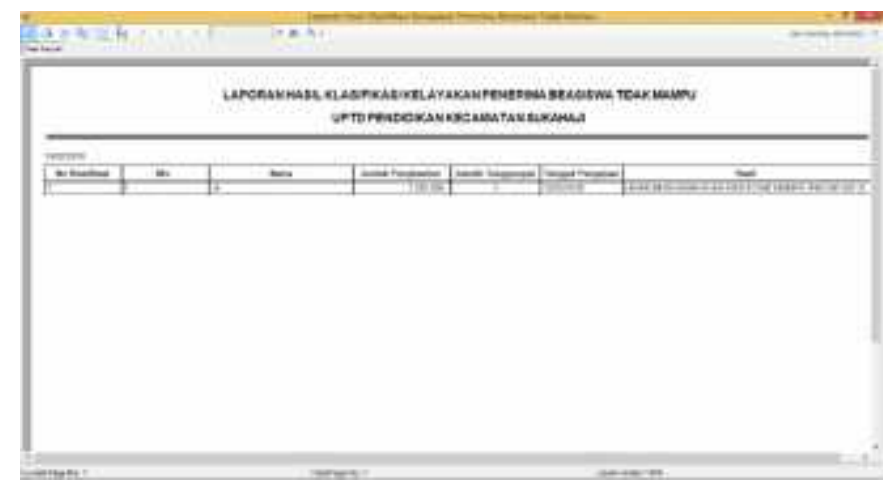

Gambar 16. Laporan Hasil Klasifikasi Kelayakan Penerima Beasiswa

\section{KESIMPULAN}

Kesimpulan Dari uraian yang terdapat pada laporan ini, maka penulis menarik beberapa kesimpulan sebagai berikut:

1. Merancang sistem pendukung keputusan dengan Ms. Visual Basic 2010 menggunakan metode AHP untuk membantu UPTD Pendidikan Kecamatan Sukahaji dalam menentukan kelayakan penerima beasiswa untuk siswa tidak mampu.

2. Aplikasi sistem pendukung keputusan ini dirancang sebagai penerapan metode AHP untuk membantu staff UPTD Pendidikan Kecamatan Sukahaji dalam menentukan kelayakan penerima beasiswa untuk siswa tidak mampu dengan lebih efektif dan efisien.

3. Adapun hasil pengujian aplikasi sistem pendukung keputusan yang menggunakan metode AHP yaitu mampu memberikan keputusan layak atau tidaknya penerima beasiswa untuk siswa tidak mampu dalam pengajuannya berdasarkan kriteria atau ketentuan dari UPTD Pendidikan Kecamatan Sukahaji yang sudah ditetapkan.

Saran-saran yang dapat penulis berikan terhadap perancangan sistem pendukung keputusan kelayakan penerima beasiswa untuk siswa tidak mampu dengan metode AHP menggunakan Visual Basic 2010 adalah:

1. Perlunya peningkatan sarana penunjang sistem, yaitu perangkat keras dan perangkat lunak yang memadai untuk menjalankan aplikasi sistem pendukung keputusan ini.

2. Agar aplikasi dapat dioperasikan dan dipahami dengan baik oleh Staff UPTD Pendidikan Kecamatan Sukahaji selaku Administrator, maka perlu diadakan pelatihan mengenai bagaimana cara penggunaan aplikasi tersebut dan dibuat panduan penggunaan aplikasi (manual book).

\section{REFERENSI}

[1] Al Fatta, H., (2007), Analisis dan Perancangan Sistem Informasi untuk Keunggulan Bersaing Perusahaan \& Organisasi Modern, ANDI : Yogyakarta.

[2] A.S. Rosa, M. Shalahuddin, (2011), Modul Pembelajaran Rekayasa Perangkat Lunak (Terstruktur dan Berorientasi Objek), MODULA : Bandung.

[3] A.S., Rosa dan M. Shalahuddin, (2013), Pembelajaran Rekayasa Perangkat Lunak (Terstruktur dan Berorientasi Objek), MODULA : Bandung.

[4] B., Al - Bahra bin Ladjamuddin, (2004), Konsep 
Sistem Basis Data dan Implementasinya, GRAHA ILMU : Yogyakarta.

[5] Fatansyah, (2012), Basis Data, INFORMATIKA : Bandung.

[6] Marlinda, L., Sistem basis data, (2004), ANDI : Yogyakarta.

[7] Safaat H., N., (2012), Pemrograman Aplikasi Mobile Smartphone dan Tablet PC Berbasis Andorid, INFORMATIKA : Bandung.

[8] Sommerville, I., (2003), Software Engeneering (Rekayasa Perangkat Lunak) jilid 1, Erlangga : Jakarta.

[9] Sommerville, I., (2003), Software Engeneering (Rekayasa Perangkat Lunak) jilid 2, Erlangga : Jakarta.

[10] Supardi, Y., (2012), Semua Bisa Menjadi Programmer Visual Basic 2010, Elex Media Komputindo : Jakarta.

[11] Sutabri, T., (2012), Analisis Sistem Informasi, ANDI : Yogyakarta.

[12] Sutabri, T., (2012), Konsep Sistem Informasi, ANDI : Yogyakarta.

[13] Sutanta, E., (2003), Sistem Informasi Manajemen, Prenhallindo : Jakarta.

[14] Tim Penyusun, (2017), Pedoman Tugas Akhir Fakultas Teknik Universitas Majalengka Jilid 1, Majalengka.

[15] Waljiyanto, (2003), Sistem Basis Data, GRAHA ILMU : Yogyakarta.

[17] Yakub, (2012), Pengantar Sistem Informasi, GRAHA ILMU : Yogyakarta. 